\title{
The Allocation of Publicly-Provided Goods to Rural Households in India: On Some Consequences of Caste, Religion and Democracy.*
}

\author{
Roger Betancourt \\ D. of Economics \\ U. of Maryland \\ College Park, MD 20742
}

\author{
Suzanne Gleason \\ Massachussetts General Hospital \\ Harvard Medical School \\ Boston, MA 02114
}

June 1999

* Research on this paper has benefitted from support provided by the U.S. Agency for International Development, under Cooperative Agreement No. DUR-0015-0031-00 to the Center for Institutional Reform and the Informal sector (IRIS), and the University of Maryland. We thank R. Vanneman and D. Barnes for making the Indian District Data Base available to us. Earlier versions of the paper were presented at the Eastern Economic Association Meetings , the U. of Maryland International Economics and Development Workshop, Rutgers U., the Western Economic Association Meetings, NEUDC and at the AEA Meetings in New York. Comments from the participants, Anand Swamy, Jon Harford, Praveen Kumar, Carlos Seiglie, M. Fafchamps and J. Nugent are gratefully acknowledged. We thank them without incriminating them. 
Coauthors: Roger Betancourt, Suzanne Gleason

Affiliations: U. of Maryland, Harvard Medical School

Title: $\quad$ The Allocation of Publicly-Provided Goods to Rural Households in India: On Some Consequences of Caste, Religion and Democracy

\begin{abstract}
:
In this study we address the following question-- what determines the allocation of publiclyprovided goods to rural households in India? Our paper is empirically driven but we draw on the characteristics of India's institutional structure and the implications of existing literature for framing the answer to this question. We confront the main empirical implications drawn from this frame of reference with a unique data set for India which brings together the widely used district data with a recently constructed data set on political participation. Our empirical results identify four important determinants of the outcomes of this allocation process: formal and informal characteristics of each state allocation mechanism, selectivity in the allocations against Muslims and scheduled castes; bureaucratic rules and behavior; and characteristics of the electoral participation process.
\end{abstract}

JEL Classification numbers: H4; D72; O18; O53

Key Words: allocation of publicly-provided goods; Tiebout; collective choice; fiscal decentralization in developing countries; rural India; empirical analysis of institutions. 
A principal aim of this paper is to raise, and to provide empirical evidence on the answer to the following question: What determines the allocation of publicly-provided goods, in particular medical and educational services, to rural households in India?

In most societies, both developed and developing, the government or state plays a critical role in providing health and education services to households as public goods. These services include, for example, access to safe drinking water, clinics and schools. While some of these goods are not pure public goods and can be privately provided, they are publicly provided in most countries and our objective is to understand this process and its consequences. In the case of India public provision is the major form of provision in rural areas. For instance, in their analysis of the health care sector in India Duggal, Nandraj and Vadair (1995) stress the inequality in access to health care between rural and urban areas and point out that access to private practitioners in rural areas is access to non-allopathic systems or to persons without any qualifications.

Fiscal decentralization in developing countries is receiving increasing attention and support among researchers, for example Oates (1997), and policy analysts, for example World Development Report (1997). Nevertheless the support is subject to qualifications. Thus, Oates stresses the importance of hard budget constraints at lower levels of government and the WDR discusses this and other 'pitfalls' of decentralization (Ch.7). Empirical work at the macro level, Davoodi and Zou (1997) and Zhang and Zou (1997), shows a negative impact for fiscal decentralization on economic growth in developing countries. Polishchuk's (1999) interpretation of Russia's experience raises considerable doubts about the benefits of this process.

The decentralization context enhances the relevance of studying the specific institutional arrangement whereby health and education services are provided to rural households in India. For, 
as we shall demonstrate in the next section, in this case the responsibility for providing these public services has been decentralized through its delegation to the state governments by the central or union government since independence. To our knowledge, no attempt has been made to provide systematic empirical evidence on the consequences of decentralization for the outcomes of this allocation process.

India's experience is also of interest because it has been a democracy for the last 50 years. Few developing countries can make this claim, especially when attention is restricted to the poorer and bigger ones. Yet, recent years have seen moves toward democracy in many developing countries. Thus, the question of how features of the democratic process affect the outcomes of the allocation process for public provision of health and education services is one of increasing relevance and it will be part of the main focus of our investigation.

The plan of the paper is as follows: In the next section we summarize the main aspects or stylized facts of India's institutional structure that condition our empirical analysis. In Section 2 we draw implications from separate bodies of literature to create a framework in which to interpret the outcomes of the allocation process for providing health and education services to households in India's rural districts. In Section 3 we discuss the details of the data, and the interpretation and measurement of the variables and econometric procedures implied by the previous discussions. In Section 4 we present the empirical results. We conclude by providing some perspective on our analysis.

1. Implications of India's Institutional Structure.

Three important characteristics of India's institutional structure are relevant for our subsequent arguments. They are to be viewed as stylized facts that condition our analysis. 
First, Indian state governments are the main decision makers in determining the allocation of health and education inputs to the local levels. They have the constitutional responsibility to do so for most health and education activities, Thakur (1995, Ch.3). They control most of the financial resources devoted to these activities. ${ }^{1}$ They have state administrative bureaucracies devoted to the implementation of these activities in the form of medical and education departments, Maheshwari (1979).

Second, elected members of the state legislatures play key roles in these allocation decisions. Government at the state level is composed of three institutions (Maheshwari,1979): the governors and the council of ministers, the secretariat and the departments. The ministers are elected members of their state legislatures and they represent the political executive; a minister is also the political head of each department making up the secretariat. The governance structures of Indian state governments that result from this arrangement are analyzed by Manor (1992) in terms of three dimensions: political ideology, managerial style, probity and effectiveness. His analysis concludes that the differences along these three dimensions among states lead to intrinsic differences in the operation of the political process in each state. ${ }^{2}$

Third, the basic unit of administration at the lower level from the state is the district (Maheshwari,1979). States' departments, for instance, have district officers with jurisdiction over the district. If a village headmaster does not get paid, for example, his main recourse is to visit the

${ }^{1}$ Indian state governments spend $84.9 \%$ (92\%) of all expenditures on education (health) by both states and the central governments, Rao (1996).

${ }^{2}$ For our purposes, this implies intrinsic differences among states in the allocation mechanisms used to provide health and education services to rural households in their districts. 
district education officer at the district seat. ${ }^{3}$ The importance of the districts is enhanced by the ineffectiveness of local government institutions below the state level. For instance, one writer gives poor ratings to attempts at promoting rural local government institutions due to their lack of autonomy, Maheshwari (1979, p.269). While the basic unit of administration is the district, the basic unit of the electoral process is the constituency. The latter is defined in terms of population and at a much lower level of aggregation than the district. Fortunately, it is possible to aggregate constituencies into the districts in which they lie. Singh and Bose (1987-88) provide a matching table.

Summing up, local outcomes with respect to the availability of health and education inputs at the district level are determined by decision makers in each state, who are politicians elected by constituencies to the state legislatures, and they do so through the mediation of state bureaucracies and subject to constraints imposed by the Center. ${ }^{4}$

2. Implications of the Literature.

Since we are interested in the provision of local public goods to households, a natural starting point is the theory of local public finance. The workhorse of this literature is the Tiebout model. ${ }^{5}$ Application of this model to developing countries has been criticized on two grounds, Ball and Linn

${ }^{3}$ Thakur (1995, p.178 ) provides a poignant illustration of this process.

${ }^{4} \mathrm{We}$ are treating state bureaucracies as including the civil servants from the Indian Administrative Services (IAS), which is a bureaucracy from the Center, because these civil servants play a role in the operation of the states' bureaucracies. They provide administrative heads, in the states' secretariats, and district collectors, who are the chief administrative officers in each district. They are few in number, fewer than 5,000 of the 17 million public employees are members of IAS (Thakur, 1995, p.166), but can influence outcomes as part of the states' bureaucracies.

${ }^{5} \mathrm{~A}$ recent statement and an interesting application of the model is provided by Kollman, Miller and Page (1997). 
(1992). First, in this model local decisions (and thus local outcomes) are seen as responsive to local demands. Second, the model assumes local finance is determined by households' mobility.

We saw in the previous section that local outcomes (at the district level in our case) are determined at a nonlocal level (namely the state level), because there are no local decisions. It is still possible, however, that local outcomes are responsive to local demands if politicians at the state level respond to these local demands. One possibility is that politicians at the state level respond to voter preferences in each district and their allocations correspond precisely to what the majority would have wanted. Another possibility is that politicians at the state level determine these allocations entirely according to their own preferences.

One way to discriminate between these two extreme alternatives is to view political participation by voters in a district as an indicator of preferences toward these allocations. If elected politicians are responsive, then the degree of political participation in a district should have an effect on local (district) outcomes; if they are not responsive, the degree of political participation should have no effect on outcomes. Notice that no prediction as to the sign of the effect follows from the argument in the former case. The sign would depend on the nature of the voter preferences over these issues.

Household mobility in the Tiebout model provides a mechanism for competition among local jurisdictions through an entry and exit process that affects the tax base. In our context, however, the districts have no local tax base. The states do have a tax base, although they face a soft budget constraint. ${ }^{6}$ Moreover, household mobility is limited in rural India. While there is internal migration

${ }^{6}$ The states were spending about $60 \%$ of all tax revenue while raising $35 \%$ in the mid 1980's (Thakur, 1995). The difference is made up through a variety of transfers from the Center. 
in India, this migration takes place within districts not across districts, Rosenzweig (1988). ${ }^{7}$ Thus, in our context the state decision makers in their allocation decisions should be viewed as spatial monopolists facing immobile customers within their local jurisdictions. More generally, the second mechanism resulting in local outcomes responsive to local demands is missing in our setting.

By modifying the standard local public finance literature in this manner, we have two extreme versions of a principal-agent model in which to frame our investigation. ${ }^{8}$ This is in line with the development literature view of the role of the state in developing countries. Lin and Nugent (1995) advocate the analysis of the role of government in terms of a principal- agent framework, where the rulers, or elected politicians in our case, act as agents for the citizens, or electorate in our case, who play the role of principals. A principal-agent framework is also consistent with the 'second generation' view of fiscal federalism, Qian and Weingast(1997).

Lin and Nugent (1995) also argue that there is a second principal-agent problem between the ruler and his agents, which in our case would be between the elected state politicians and the state bureaucracies. From our point of view, it does not matter whether one views this issue as a second principal-agent problem or as providing a constraint on the first principal-agent problem. What matters is that both views suggest that features of bureaucratic behavior will affect local outcomes. The literature on bureaucracy, for example Niskanen (1971 ), indicates the existence of rules, for example based on geography or population, that expand the size of the bureaucracy. These rules

${ }^{7}$ It is possible that migration patterns have changed since the Rosenzweig study, but our district data comes from the 1981 Census which is precisely the period when this conclusion would apply.

${ }^{8} \mathrm{An}$ in between alternative also follows from our arguments. Namely, elected politicians respond imperfectly to local demands and indulge their preferences to some extent in their allocation decisions. 
would affect the outcomes of any allocation mechanism for the provision of public services. Of course, these practices have their limits because bureaucracies also have incentives to provide public services at low costs. ${ }^{9}$

Considering India's history on caste and religion and a setting where the preferences of decision makers can play a role in the allocation of health and education inputs to the districts, the possibility of discrimination against certain castes or religious groups must be considered. This can happen because the political process allows the elected state politicians (and/or their bureaucratic mediators) to indulge their preferences, or because the political process leads elected state politicians to indulge the preferences of the majority voters in each district. Discrimination is more likely in a setting where the agent at the state level can indulge his or her preferences than where the agent is following the preferences of the majority voters in a district. The latter case requires mechanisms, for example spatial segregation of the discriminated group within a district, where majority voters do not injure their own interests in this process, or alternatively assuming that it is rational for them to injure themselves.

Since the second (entry and exit) mechanism for ensuring that local outcomes in the allocations of health and education inputs are responsive to local demands does not operate in our context, the possibility of interests groups affecting outcomes is greater than in a more competitive setting. Interest groups are more easily organized when they are small and homogeneous, Olson (1965). In the case of India, Swamy (1998) provides evidence in his analysis of farmers' movements that these are controlled by rich and middle class farmers and that, while they may have an 'encompassing

${ }^{9}$ For instance, Findlay (1991) develops a model where it is optimal for the bureaucratic state to minimize costs in overproviding the level of a public good that increases market output. 
interest ${ }^{10}$ with respect to productivity, they have neglected the provision of social services such as health and education.

Last but not least we draw from the public choice and political science literature on political participation. In general this literature has viewed political participation as consumption behavior and its emphasis is on the determinants of participation rather than on the consequences of participation, as noted by Leighley (1995). ${ }^{11}$ An exception to the above conclusion is the strand of literature concerned with female political participation, which notes that the legislative behavior of females in the U.S. differs from that of males. More specifically, females introduce bills that focus on medical and educational issues while males tend to focus on business bills, e.g., Thomas (1991) and Thomas and Welch (1991). This literature suggests that, if there is any effect of political participation on the allocation of publicly provided goods, there would be a differential effect of participation by males and females on the allocation of health and education inputs.

Summing up, the implications drawn from the literature in this section are that local outcomes in a district of the allocation process for health and education inputs are a function of the following sets of variables: characteristics of the political process that affect the interaction between the principals or electorate and the agents or elected politicians; characteristics of groups in the district that may

${ }^{10} \mathrm{An}$ interest is encompassing if it benefits the interest group or those who control it as well as others outside the group or those in the group who do not control it. More recently, McGuire and Olson(1996) use the notion of a superencompassing interest to describe a situation where, under majority rule, it does not pay the majority to redistribute to itself from minorities, because the distortionary effects of taxation and the need to provide a public good that affects market output would lower their welfare.

${ }^{11}$ Early references are Frey (1971,1972), Russell (1972), Fraser (1972) and Crain and Deaton (1978). Recent literature on political participation augments the standard economic approach embedded in the earlier work by introducing sociological and psychological variables as well as the role of institutions, e.g., Fowler (1993), but continues its focus on the determinants of voting behavior. 
be the target of discrimination by the agents or the principals; characteristics of the districts that facilitate or hinder the operation of interest groups with special interest ( or lack thereof) in the outcomes of the allocation process; and, characteristics of the districts that facilitate or hinder the operation of rules rewarded by bureaucracies.

\section{Data, Measurement and Estimation Procedures.}

Two primary data sources underlie our empirical investigation. The first one is a cross-section of the Indian Development District Data, Vanneman and Barnes ( 1993, Release 3). The data is compiled from the 1981 Indian Census as well as many secondary sources. ${ }^{12}$ The second data source is the Indian Election Data for the Vidhan Sabha or state level elections, Gleason (1996, Appendix B, part II). It contains a variety of electoral data for about 3000 constituencies for the state elections in 1977-78 which, as mentioned earlier, can be aggregated to the administrative district in which they lie using Singh and Bose's (1987-88) matching table.

All the variables used in the empirical analysis, except for the political participation ones and the number of constituencies, come from the first data base. We are able to identify three variables associated with the provision of health and education services made available to rural households by the state governments: $y_{1}$ is the number of doctors in a district's rural areas; $y_{2}$ is the number of nurses and other health technicians in a district's rural areas; $y_{3}$ is the number of teachers in a district's rural areas. All of them are measured relative to the district's rural population, i.e., per 10 persons in the rural areas of a district. All three dependent variables take on values in the zero to one interval, which can be seen from the descriptive statistics for the variables used in the analysis

\footnotetext{
${ }^{12}$ This data set has been widely used but the focus of the analysis is always on the explanation of individual behavior, for example variations in fertility rates (Murthi, Guio and Dreze (1995) or variations in child mortality rates (Gleason,1997). Here, we will be focusing on the explanation of the behavior of state governments.
} 
presented in Table 1. The first two variables generate indexes of medical services and the third one of educational services provided by the states. ${ }^{13}$

Political participation will be measured by: voter turnout, or the ratio of total voters in the district to total registered voters ${ }^{14}$, and the voting ratio, or the ratio of female voters to male voters in the district. Both are taken from the 1977/78 State Legislative elections. If voter turnout has no effect on the allocations, it can be interpreted as evidence that the voice mechanism fails and the state level decision makers can indulge their preferences. If it has an effect, it can be interpreted as evidence that the voice mechanism is operating and the state level agents are responsive, at least to some extent, to voter preferences. The sign of the effect in this case would be an indication of voter preferences with respect to their demand for a particular input ( more or less). Given the literature on political participation by females in advanced countries, we would expect the voting ratio to have a positive effect on the allocation of these inputs to the district when state level decision makers are responsive to differential participation by gender.

Since the responsiveness of the political system to a district's concerns may be influenced by the number of representatives a district has, which is determined by the number of constituencies within a district, we used the number of constituencies in a district as an independent variable. Because

${ }^{13}$ Ideally, we would want to measure these services in efficiency units, i.e., corrected for the efficency with which they are provided. The impact on well-being of a teacher or doctor that does not show-up, for instance, is quite different from one that, at least, is present. These data do not exist. Substitutes reflecting outcomes, for example literacy or infant mortality rates, do exist. Nonetheless, they would confound the analysis because they are the joint outcome of availability, efficiency and intervening household decisions. The ones we use are clearly the result of the decisions of agents in state governments and, thus, capture the distinctive focus of our analysis.

${ }^{14}$ It is worth noting that in India the responsibility for registering voters lies with the government not the individual. Hence, the total number of registered voters should coincide with the population over 21 years of age, except for the insane and convicted felons. 
constituencies are based on population, more urbanized districts have more constituencies. Hence, the sign of this variable is an indicator of bias in the allocation mechanisms due to a political process based on population and a public administration system based on the British colonial legacy: urban bias, if negative; rural bias, if positive.

The proportion of scheduled castes and of Muslims in the rural area of a district are indicators of the presence of groups that maybe the target of discrimination. We would expect these variables to have a negative effect on outcomes if there is discrimination. Our interpretation from the discussion in the previous section is that this would be due to the ability of agents, rather than principals, to indulge their preferences in this institutional setting. It is also possible, however, that this is due to other reasons, including characteristics of the states' allocation processes not captured elsewhere in our analysis.

Two variables are used to capture the potential effects of special interest group activities. We included agricultural output per person in a district as an explanatory variable. It was measured as the total production in a district of 37 crops for which there is price data ( valued in 1000's of 1971 rupees) divided by the number of persons in the rural area of the district. If Swamy's interpretation of the farmers' movement is correct, richer districts should have more resources to 'persuade' state level decision makers and the neglect of social services should be greater in these districts.

We also included a variable in the analysis that captures wealth concentration or inequality. Namely, the proportion of farm workers in a district who are laborers, not cultivators. This variable can serve as an indicator of the ease (inverse indicator of cost) with which special interest groups in rural areas of a district may be organized for two different reasons. The fewer the members the easier it is for the haves to organize; the sharper the class distinctions between haves 
and have nots, the more homogeneous the interests of both groups and the easier it is for both of them to organize. The sign of this variable, however, depends on two things: whether or not the effects of homogeneity on the have nots dominate the effects of low numbers and homogeneity among the haves in allowing each to organize and the purpose for which these special interest groups organize. ${ }^{15}$

The next two variables try to identify bureaucratic characteristics that may affect the allocation of health and education services. If there are either geographical or demographic allocation rules followed by a bureaucracy, they should affect the outcomes that we observe. Thus, the bigger the area per person in a rural area of a district, measured in square kilometers per person or the inverse of rural population density in a district, the more of the above inputs will be needed to provide a given level of access to public services in the rural areas of a district. If a bureaucratic rule based on geography is in place, we should observe a positive effect on outcomes. On the other hand, if a bureaucratic rule based on population is in place, we should observe a negative effect. Another variable that captures bureaucratic features is the percentage of the urban population in a district. The greater this percentage, the more likely there is a greater supply of trained personnel such as nurses, doctors and teachers as well as low cost access to rural areas. Thus, the cheaper it is to supply the rural areas of a district with this type of personnel and we should observe a positive effect on outcomes.

${ }^{15} \mathrm{~A}$ plausible interpretation would be to assume the have nots organize to increase the allocation of these inputs to their districts and the haves organize to lower the allocation of these inputs to their districts, either for the reasons given above or to lower their state taxes. In this case, a positive coefficient implies the homogeneity of interests of the have nots dominates in allowing them to organize themselves, or that it is thus perceived by the agents. 
In addition to the nine independent variables just described, we introduced a dummy variable for each state in our sample. These state dummies capture fixed effects that are common to all districts within a state but vary across states due to variations in the allocation mechanisms for each state. Our discussion of the Indian institutional structure leaves no doubt about the necessity of controlling for state effects.

Summing up our arguments in a suitable form for empirical analysis, we postulate the following relationship between the outcomes of the allocation mechanism for providing health and education services to rural households in a district and the characteristics or features of these mechanisms discussed here.

$y_{i j}=e^{\hat{a} X(i, j)} /\left(1+e^{\hat{a} X(i, j)}\right)+\stackrel{\circ}{i j}_{i j}=1,2,3$.

The vector $X(\mathrm{i}, \mathrm{j})$ includes the nine variables individually identified and a set of 17 state dummy variables. ${ }^{16}$ Since our dependent variables lie in the zero to one interval, the logit specification was adopted to ensure that the predicted values fall within the 0-1 interval.

The equations in (1) were estimated as a system because one might expect the disturbance terms to be correlated across equations $(\mathrm{j})$ for any one district $(\mathrm{i}=1, \ldots, 325) .{ }^{17}$ For instance, there may be a trade-off in the allocation process for a district between education and health personnel or between different types of health personnel; alternatively, some aspects of the budgetary allocations

${ }^{16}$ The included states are: Andhra Pradesh, Bihar, Haryana, Himachal Pradesh, Jammu \& Kashmir, Kerala, Karnataka, Madhya Pradesh, Maharastra, Meghalaya, Nagaland, Orissa, Punjab, Rajahstan, Tamil Nadu, Uttar Pradesh, West Bengal.

${ }^{17}$ Of the 378 districts in the original 1981 Census file we were left with 325 districts with usable data for our purposes. For instance, 8 districts in Assam had no census data due to civil strife. 26 districts had missing data on the political variables. 4 districts were 100\% urban. 6 districts had missing census data. 8 districts were aggregated into 4 districts because they were split after the 1977-1978 elections. Finally, 5 districts were eliminated because they were union territories and, thus, centrally administered. 
from the central to the state governments may affect all trained personnel in a district in the same manner. ${ }^{18}$ Since heteroskedasticity across districts can be expected,${ }^{19}$ we use robust estimates of the variance covariance matrix throughout.

It can be argued that there exists a reverse causation between the level of political participation in a district and the dependent variables in our model. That is, the levels of these public goods may influence the extent of political participation by the electorate. While our political participation variables precede in time the dependent variables, Deaton (1995) has argued that the existence of persistence effects in a cross-section generates simultaneity problems despite the precedence in time of explanatory variables. Since our dependent variables are stocks, persistence effects are likely to exist. Therefore, we have used two estimation methods: seemingly unrelated regressions (SUR) and nonlinear three stage least squares (NL3S). ${ }^{20}$

Our choice of variables to use in the instruments matrix for NL3S, besides the included exogenous variables, were the ratio of female to male population in a district and its square as well as the squares of four other exogenous variables: proportion of scheduled castes, proportion of rural

${ }^{18}$ We experimented with a larger system that included an equation with the number of administrators per 10 persons in the district as a dependent variable. The results for doctors, nurses and teachers are not affected by inclusion of this additional equation. We restrict our attention to the smaller system because the category administrators is a heterogeneous one in terms of the public goods provided by these civil servants and, thus, difficult to interpret.

${ }^{19}$ Districts vary considerably in terms of population; unless the variations in doctors , teachers and nurses across districts are proportional to the variations in population, one would expect heteroskedasticity to be present between districts.

${ }^{20}$ We performed the Hausman exogeneity test, applying the procedure described in Pyndick and Rubinfeld (1991) to our analysis, and rejected the null hypothesis of exogeneity at the $1 \%$ level for both political participation variables. 
Muslims, rural land per person and urbanization. ${ }^{21}$ One issue that arises here is whether or not the variables selected as instruments belong directly in the regression as explanatory variables. We employed the overidentification test suggested by Davidson and Mckinnon (1993, pp. 232-237) to determine whether or not each of the six additional instruments were proper instruments. The results of the test were that rural land per person squared should be included as an explanatory variable directly in the doctors and nurses equations and the proportion of rural Muslims squared should be included directly as an explanatory variable in the teachers equation. With this adjustment the null hypothesis that the remaining five additional instruments in each equation are proper instruments can not be rejected at the $1 \%$ level of significance. Hence, the resulting model specification is referred to in the Tables below as the selected model.

\section{Results.}

Tables $2 \mathrm{~A}-2 \mathrm{C}$ present the results of estimating two alternative model specifications of the system in equation (1) by SUR and NL3S as well as the model specification selected by the overidentification test discussed in the previous paragraph. The main entry in each cell reports the marginal effects as elasticities measured at the sample means, i.e., the elasticity of the dependent variable with respect to the independent variable measured at the means of both. For instance, the entry in the row for proportion urban under the selected model column in Table $2 \mathrm{~A}$ tells us that a

${ }^{21}$ In the nonlinear case use of powers of the exogenous variables as additional instruments in the first stage reduces the variances of the estimators in the subsequent stage provided the sample size is not significantly reduced as a result, for example Kelejian and Oates (1981, pp. 299-300). In addition, we checked the sensitivity of the results to these instruments by adding the squares of agricultural output and proportion of landless to the list. The results were the same in both cases. 
$1 \%$ increase in urban population in a district increases the number of doctors per 10 persons in a district by $0.17 \% .^{22}$

One of our most systematic and robust results is that the features of each state common to all districts within a state are important determinants of the provision of these three public inputs to the rural districts. All 17 state dummies are significantly different from zero at the $1 \%$ level in every specification presented in Tables 2A-C. Since we do not present the individual dummies for reasons of space, the last row of Tables $2 \mathrm{~A}-\mathrm{C}$ shows the pseudo $\mathrm{R}^{2}$ obtained when the state dummies are excluded. In every instance there is a substantial reduction in predictive power from excluding the state dummies; these reductions range from $18 \%$ to $56 \%$ of the variation in the dependent variable over the 15 combinations of model specification and estimation method. In the selected model specification (last column) $38 \%, 18 \%$ and $40 \%$ of the variation in doctors, nurses and teachers, respectively, allocated to rural areas of each district is accounted for by variations between states in factors that are common to all districts within the state. One such factor would be, for example, formal and informal allocation rules within each state and their interactions.

A second systematic and robust result is the existence of statistical discrimination in the outcomes of the allocation process on the basis of caste and religion. A higher proportion of Muslims in the rural area of a district leads to a lowering of the public input in each equation, for every model specification and with both estimation methods. ${ }^{23}$ A similar result holds for scheduled

${ }^{22}$ The preferred model specification is the one in the last column of each table. Our statements will refer to these results unless indicated otherwise in the text. For simplicity of exposition we treat a result as statistically insignificant if the t-ratio is less than 2 , which implies levels of significance lower than $5 \%$ for two sided hypotheses and $2.5 \%$ for one sided ones.

${ }^{23}$ In the selected model specification for the teachers equation the relationship is nonlinear, but the sign of the effect will always be negative. Since the independent variable takes on values only between zero and unity, the squared term is always smaller than the linear one and, thus, the 
castes with one exception, namely the selected model specification in the teachers equation. This discrimination is the consequence of decisions by the states and thus it suggests a role for the preferences of the state agents in determining these outcomes. Nevertheless we have no direct knowledge of how this statistical discrimination arises ${ }^{24}$ or of alternative mechanisms generating the statistical result. For instance one could argue that Muslims demand fewer educational and medical personnel from public providers to accommodate their religious beliefs with respect to interactions between genders. What is robust statistically is that the outcomes of the allocation process are characterized by selectivity against scheduled castes and Muslims who live in rural areas of a district.

A third systematic and robust result is that bureaucratic aspects of behavior play an important role in determining the outcomes of the allocation process. Bureaucratic rules based on geography or population have systematic effects on the allocation of doctors, nurses and teachers to rural districts. In the case of doctors and nurses the effect is nonlinear with rural districts bigger in area per person receiving greater allocations at a diminishing rate, which leads to smaller overall allocations once size is 1.95 (8.2) standard deviations above the mean district size for doctors (nurses). The effect for teachers is linear with bigger rural districts in area per person receiving greater allocations throughout. A higher proportion of urban population in a district increases the provision of medical services to the rural areas of this district in the form of doctors and nurses and other health technicians, but it has no effect on the provision of teachers. This suggests that lower

negative term always dominates.

${ }^{24}$ Incidentally, we analyzed the estimated elasticities for scheduled castes and muslims by obtaining the estimate for each state and grouping them by per capita income. No pattern emerged from this analysis that would justify statements of the form -- discrimination is greater in low (or high) income states. 
costs to the state bureaucracies of providing medical services in rural areas of more urbanized districts do increase the availability of these services. The lack of a similar effect for teachers may be due to the greater abundance of this resource. ${ }^{25}$

Examining the impact of aspects of the political process on the outcomes of allocation processes with respect to medical and educational services is one of our main objectives. We find that higher voter turnout in a district increases (decreases) the allocation of nurses (teachers) to rural areas of a district and it has no effect on the allocation of doctors. This result is suggestive of constraints in the ability of state governments to respond to political participation by voters through their allocation of these publicly-provided inputs. ${ }^{26}$ Doctors are expensive and scarce and the states are not responsive in this dimension. While nurses are also scarce, they are also less expensive than doctors and the states respond by increasing nurses and decreasing teachers allocated to the rural areas of districts. A higher female to male voting ratio in a district increases the allocations of doctors and teachers to the rural areas of these districts while having no effect on the allocation of nurses. Thus, this result suggests that Indian women emphasize similar issues to their American counterparts through their political participation and states governments respond to this emphasis in their allocation decisions with respect to publicly provided health and education inputs. Finally, a higher number of constituencies in a district decreases the number of nurses allocated to rural areas of a district while having no effect on the allocation of doctors and teachers. We interpret these results as providing weak evidence for the hypothesis that an electoral system based on constituencies

${ }^{25}$ Doctors and nurses are far scarcer than teachers in rural India, see Table 1.

${ }^{26}$ One would expect the demand for the services of doctors by the principals to be at least as strong as for the services of nurses. Hence, if politicians were responsive to these local demands, we would expect at least as strong an effect for doctors as for nurses, other things equal. 
coupled with an administration system based on districts generates urban bias in these allocation processes.

Special interest group variables are of limited statistical importance in explaining the allocation processes for these publicly provided inputs. Their effects are not robust across model specifications or estimation methods. In the preferred model specification neither variable has an effect on the provision of medical service inputs while only the proportion of landless has an effect on the provision of educational service inputs. Its sign suggests that ease of organization by the have nots induces the states governments to respond by increasing the allocation of teachers to rural areas of a district. The negative sign of the effect of agricultural output per person on outcomes is consistent with Swamy's conclusion that farmers' movements as a special interest group have neglected social services, since we would have expected districts where they can draw on more resources to 'persuade' agents at the state level to have lower allocations of teachers and medical inputs. Nonetheless the result lacks statistical significance in the preferred model specification.

\section{Concluding Remarks.}

By putting together the widely used district data with a recently constructed data set on political participation, we have constructed a unique data set which can be used to address important questions that have not been asked before. Namely, what determines the allocation of publiclyprovided health and education services to households in India's rural districts? and what features, if any, of the democratic process play a role in these allocation processes?

From studying the main characteristics of India's institutional structure we identify key features of the allocation process which condition our empirical analysis. Namely, in India the state governments are the crucial decision makers and, thus, their characteristics and their interactions 
with their environments are generating the allocation outcomes for their districts. We control for unobserved characteristics that vary across states, but not across districts within a state, and find them to be important in explaining allocations of medical and educational services to rural districts. Identifying the observables among these unobserved characteristics and determining whether or not they matter may be a useful undertaking.

We also identify a set of characteristics of districts, which can be interpreted in terms of a principal-agent framework and prior literature, as determinants of these allocation outcomes. Among the empirical regularities we find for these district characteristics are that variables associated with caste and religion, bureaucratic rules or behavior, and participation in the electoral process play a robust and substantial role in determining the outcomes observed for rural districts. For instance, these variables explain $14 \%, 40 \%$ and $15 \%$ of the variation in the allocation of doctors, nurses and teachers, respectively, to rural districts. Controlling for unobserved characteristics of districts by looking at panel type of data would enhance our confidence in these empirical regularities, but it is a difficult task in terms of data requirements.

More generally, our results suggest that in the context of Indian democracy, despite state decision makers that are responsive to electoral participation in the districts, decentralization to the intermediate levels of government affords opportunities for state agents to allocate medical and educational inputs in ways that the principals in the local rural districts are unlikely to endorse. Whether or not further devolution to the local level would improve outcomes is a worthy question for future research. 
References

Ball, Roy W. and Johannes F. Linn. 1992. Urban Public Finance in Developing Countries, Oxford: Oxford University Press.

Crain, W. Mark, and Thomas H. Deaton. 1978. “A Note on Political Participation as Consumption Behavior," Public Choice, 32, pp. 131-135.

Davidson, Russell and James G. MacKinnon. 1993. Estimation and Inference in Econometrics, Oxford: Oxford university Press.

Davoodi, Hamid, and Heng-fu Zou. 1997. "Fiscal Decentralization and Economic Growth: A Cross- Country Study," Journal of Urban Economics, forthcoming.

Deaton, Angus. 1995. "Data and Econometric Tools for Development Analysis," in J. Behrman and T.N. Srinivasan (eds.) Handbook of Development Economics (vol. IIIA ), Amsterdam: North Holland Press.

Duggal, Ravi, Sunil Nandraj and Asha Vadair. 1995. "Health Expenditures across States-Part I," Economic and Political Weekly. April 15.

Findlay, Ronald. 1991. "The New Political Economy: Its Explanatory Power for LDC's," in Gerald Meier (ed.) Politics and Policy Making in Developing Countries: Perspectives on the New Political Economy, San Francisco: International Center for Economic Growth.

Fowler, Linda L. 1993. Candidates, Congress and American Democracy, Ann Arbor: University of Michigan Press.

Fraser, John. 1972. "Why do High Income People Participate more in Politics? The Wrong Answer," Public Choice, 13, pp. 115-18. 
Frey, Bruno S. 1971. "Why Do High Income People Participate More in Politics?” Public

Choice, 11, pp.101-105. 1972. "Reply," Public Choice, 13, pp. 119-22.

Gleason, Suzanne. 1997. “ Public Goods and Intrafamily Resource Allocation: Female Child Survival in India," mimeo, College Pk. Md.: D. of Economics, U. of Maryland. 1996. Female Well-being and Public Goods, Ph. D. Thesis, University of Maryland,

College Park.

Kelejian, Harry H. and Wallace E. Oates. 1981. Introduction to Econometrics: Principles and Applications.New York: Harper \& Row Publishers.

Kollman, Ken, John H. Miller and Scott E. Page.1997. "Political Institutions and Sorting in a Tiebout Model," American Economic Review, 87, pp. 997-92.

Leighley, Jan E. 1995. “Attitudes, Opportunities and Incentives: A Field Essay on Political Participation," Political Research Quarterly, 48, pp. 181-209.

Lin, Justin Yifu and Jeffrey B. Nugent. 1995. “Institutions and Economic Development,” in J. Behrman and T.N. Srinivasan (eds.) Handbook of Development Economics (vol. IIIA), Amsterdam: North Holland Press.

Maheshwari, Shriram. 1979. State Governments in India. Delhi: The MacMillan Company of India Limited.

Manor, James. 1992. “The State of Governance,” in Subroto Roy and William James (eds.). Foundations of India's Political Economy: Towards an Agenda for the 1990's, New Delhi: Sage Publications India Pvt Ltd. 
Mcguire, Martin C. and Mancur Olson, Jr. 1996. “The Economics of Autocracy and Majority Rule,” Journal of Economic Literature, 34, 72-96.

Murthi, Mamta, Anne-Catherine Guio and Jean Dreze. 1995. "Mortality, Fertility and Gender Bias in India: A District-Level Analysis," Population and Development Review, 21, 745-82.

Niskanen, William. 1971. Bureaucracy and Representative Government, Chicago: AldineAntherton.

Oates, Wallace E. 1997. "Fiscal Federalism," mimeo, College Pk., Md.:D. of Economics, U. of Maryland.

Olson, Mancur. 1965. The Logic of Collective Action, Cambridge ( Mass.): Harvard University Press.

Politshchuk, Leonid. 1999. “Decentralization in Russia: Impact for Quality of Governance,"paper presented at the IRIS Center Conference: Collective Action and Corruption in Emerging Economies.

Pyndick, Robert S. and Danile L. Rubinfeld. 1991. Econometric Models \& Economic Forecasts, New York: McGraw-Hill, Inc.

Qian, Yingyi and Barry R. Weingast .1997. "Federalism as a Commitment to Preserving Market Incentives," Journal of Economic Perspectives, 11, 83-92.

Rao, M. Govinda. 1996. “Intergovernmental Fiscal Relations in a Planned Economy:The Indian Case," mimeo, Canberra: Australia South Asia Research Centre, Australian National University. Rosenzweig, Mark R. 1988. "Labor Markets in Low-Income Countries," in H. Chenery and T.N.Srinivasan (eds.) Handbook of Development Economics (vol. I), Amsterdam: NorthHolland. 
Russell, Keith, P. 1972. "Political Participation and Income Level: An Alternative Explanation," Public Choice, 13, pp.113-14.

Singh, V.B. and Shankar Bose. 1987-88. Elections in India: Data Handbook on Lok Sabha and Vidhan Sabha Elections 1952-85, New Delhi: Sage Publications.

Swamy, Anand. 1998. "Cooperation, Conflict, and Economic Development in India:An Analysis of the Farmers' Movements," in S. Kakkonen and M. Olson (eds.) A Not So Dismal Science, New Delhi: Sage/Vistar Publications (forthcoming).

Thakur, Ramesh. 1995. The Government and Politics of India, New York: St.Martin's Press. Thomas, Sue. 1991. "The Impact of Women on State Legislative Policies," The Journal of Politics, 53(4) pp. 958-976.

Thomas, Sue and Susan Welch. 1991. "The Impact of Gender on Activities and Priorities of State Legislators," The Western Political Quarterly, 44(2) pp. 445-56.

Vanneman, Reeve and Douglas Barnes. 1993. Indian District Data, 1961-1981 : Electronic Data File and Codebook, College Pk., Md.: Center on Population, Gender and Social Inequality. World Bank.1997. World Development Report, New York: Oxford University Press. Zhang, Tao, and Heng-fu Zou. 1997. "Fiscal Decentralization, Public Spending, and Economic Growth in China," mimeo, World Bank, Policy Research Department. 
Table 1: Summary Statistics

\begin{tabular}{|c|c|c|c|c|}
\hline Variable & Mean & $\begin{array}{l}\text { Standard } \\
\text { Deviation }\end{array}$ & Minimum & Maximum \\
\hline Doctors per 10 Population & 0.0053 & 0.0028 & 0.0013 & 0.0163 \\
\hline Nurses per 10 Population & 0.0052 & 0.0033 & 0.00073 & 0.0319 \\
\hline Teachers per 10 Population & 0.042 & 0.019 & 0.014 & 0.130 \\
\hline $\begin{array}{l}\text { Proportion of Eligible Population Voting in } \\
\text { 1977-78 State Assembly Elections }\end{array}$ & 0.58 & 0.13 & 0.26 & 0.83 \\
\hline Female/Male Voter Turnout Ratio & 0.75 & 0.19 & 0.31 & 2.14 \\
\hline Number of Voting Constituencies & 10.05 & 6.77 & 1 & 60 \\
\hline Proportion Scheduled Caste & 0.18 & 0.082 & 0 & 0.53 \\
\hline Proportion Muslim & 0.094 & 0.142 & 0.00041 & 0.98 \\
\hline Agricultural Productivity ('000 per capita) & 0.22 & 0.15 & 0.011 & 1.04 \\
\hline Proportion Landless & 0.33 & 0.19 & 0.0033 & 0.79 \\
\hline Rural Land per Person & 0.10 & 0.45 & 0.0030 & 7.92 \\
\hline Proportion Urban & 0.19 & 0.12 & 0.01 & 0.76 \\
\hline
\end{tabular}


Table 2A: Doctors(Abs. Values of t-statistics)

\begin{tabular}{|c|c|c|c|c|c|}
\hline Variable & \multicolumn{2}{|c|}{ SUR Estimates } & \multicolumn{2}{|c|}{ NL3SLS Estimates ${ }^{1}$} & Selected Model ${ }^{2}$ \\
\hline Voter Turnout & $\begin{array}{c}0.79 \\
(3.25)\end{array}$ & $\begin{array}{c}0.45 \\
(1.89)\end{array}$ & $\begin{array}{c}1.56 \\
(2.22)\end{array}$ & $\begin{array}{c}0.42 \\
(0.70)\end{array}$ & $\begin{array}{c}1.29 \\
(1.60)\end{array}$ \\
\hline Female/Male Voter Turnout & $\begin{array}{c}0.14 \\
(1.85)\end{array}$ & $\begin{array}{c}0.12 \\
(1.83)\end{array}$ & $\begin{array}{c}0.60 \\
(2.12)\end{array}$ & $\begin{array}{c}0.38 \\
(1.53)\end{array}$ & $\begin{array}{c}0.71 \\
(3.02)\end{array}$ \\
\hline Number of Voting Constituencies & $\begin{array}{r}-0.042 \\
(0.87)\end{array}$ & $\begin{array}{l}-0.11 \\
(2.19)\end{array}$ & $\begin{array}{r}-0.076 \\
(1.34)\end{array}$ & $\begin{array}{r}-0.089 \\
(1.87)\end{array}$ & $\begin{array}{c}-0.082 \\
(1.66)\end{array}$ \\
\hline Proportion Rural Scheduled Caste & $\begin{array}{c}-0.26 \\
(3.31)\end{array}$ & $\begin{array}{l}-0.25 \\
(3.43)\end{array}$ & $\begin{array}{c}-0.27 \\
(3.62)\end{array}$ & $\begin{array}{l}-0.22 \\
(2.94)\end{array}$ & $\begin{array}{c}-0.23 \\
(2.93)\end{array}$ \\
\hline Proportion of Rural Muslims & $\begin{array}{r}-0.086 \\
(4.26)\end{array}$ & $\begin{array}{c}-0.084 \\
(3.89)\end{array}$ & $\begin{array}{c}-0.10 \\
(3.56)\end{array}$ & $\begin{array}{r}-0.079 \\
(3.24)\end{array}$ & $\begin{array}{c}-0.091 \\
(3.10)\end{array}$ \\
\hline Agricultural Output per Person & & $\begin{array}{r}-0.075 \\
(1.80)\end{array}$ & & $\begin{array}{r}-0.027 \\
(0.46)\end{array}$ & $\begin{array}{c}-0.078 \\
(1.07)\end{array}$ \\
\hline Proportion Landless & & $\begin{array}{c}0.17 \\
(2.12)\end{array}$ & & $\begin{array}{l}0.072 \\
(0.71)\end{array}$ & $\begin{array}{l}-0.040 \\
(0.32)\end{array}$ \\
\hline Rural Land per Person & & $\begin{array}{c}0.0048 \\
(2.66)\end{array}$ & & $\begin{array}{c}0.0040 \\
(1.70)\end{array}$ & $\begin{array}{l}0.065 \\
(2.61)\end{array}$ \\
\hline Proportion Urban & & $\begin{array}{c}0.17 \\
(4.80)\end{array}$ & & $\begin{array}{c}0.17 \\
(4.77)\end{array}$ & $\begin{array}{c}0.17 \\
(4.43)\end{array}$ \\
\hline Rural land per person Squared & & & & & $\begin{array}{l}-0.074 \\
(2.48)\end{array}$ \\
\hline Pseudo R-Squared & 0.57 & 0.62 & 0.47 & 0.60 & 0.52 \\
\hline Pseudo R-Squared omitting State Effects & 0.16 & 0.23 & 0.01 & 0.07 & 0.14 \\
\hline & r of & $=325$ & & & \\
\hline
\end{tabular}

${ }^{1}$ Original set of instruments (all exogenous variables, female to male ratio and its square, and squares of scheduled castes, muslims, land and urban).

${ }^{2}$ Instruments selected by overidentification test (all exogenous variables, female to male ratio and its square, and squares of castes, muslims and urban). 
Table 2B: Nurses (Abs. Values of t-statistics)

\begin{tabular}{|c|c|c|c|c|c|}
\hline Variable & \multicolumn{2}{|c|}{ SUR Estimates } & \multicolumn{2}{|c|}{ NL3SLS Estimates ${ }^{1}$} & Selected Model ${ }^{2}$ \\
\hline Voter Turnout & $\begin{array}{c}0.71 \\
(2.07)\end{array}$ & $\begin{array}{c}0.13 \\
(0.54)\end{array}$ & $\begin{array}{c}4.42 \\
(3.02)\end{array}$ & $\begin{array}{c}0.79 \\
(1.42)\end{array}$ & $\begin{array}{c}2.37 \\
(2.58)\end{array}$ \\
\hline Female/Male Voter Turnout & $\begin{array}{c}-0.17 \\
(1.11)\end{array}$ & $\begin{array}{c}-0.32 \\
(2.18)\end{array}$ & $\begin{array}{c}0.69 \\
(1.66)\end{array}$ & $\begin{array}{l}-0.050 \\
(0.22)\end{array}$ & $\begin{array}{c}0.29 \\
(1.07)\end{array}$ \\
\hline Number of Voting Constituencies & $\begin{array}{l}-0.097 \\
(1.46)\end{array}$ & $\begin{array}{c}-0.11 \\
(2.23)\end{array}$ & $\begin{array}{l}-0.25 \\
(2.64)\end{array}$ & $\begin{array}{c}-0.14 \\
(2.56)\end{array}$ & $\begin{array}{c}-0.15 \\
(2.26)\end{array}$ \\
\hline Proportion Rural Scheduled Caste & $\begin{array}{c}-0.62 \\
(4.18)\end{array}$ & $\begin{array}{c}-0.35 \\
(5.19)\end{array}$ & $\begin{array}{c}-0.75 \\
(5.63)\end{array}$ & $\begin{array}{c}-0.43 \\
(5.58)\end{array}$ & $\begin{array}{c}-0.50 \\
(4.88)\end{array}$ \\
\hline Proportion Rural Muslim & $\begin{array}{c}-0.15 \\
(3.87)\end{array}$ & $\begin{array}{c}-0.11 \\
(5.11)\end{array}$ & $\begin{array}{c}-0.26 \\
(6.11)\end{array}$ & $\begin{array}{c}-0.13 \\
(5.21)\end{array}$ & $\begin{array}{c}-0.17 \\
(4.68)\end{array}$ \\
\hline Agricultural Output per Person & & $\begin{array}{c}-0.16 \\
(2.35)\end{array}$ & & $\begin{array}{c}-0.11 \\
(1.51)\end{array}$ & $\begin{array}{c}-0.15 \\
(1.78)\end{array}$ \\
\hline Proportion Landless & & $\begin{array}{l}0.019 \\
(0.31)\end{array}$ & & $\begin{array}{l}-0.081 \\
(1.12)\end{array}$ & $\begin{array}{c}-0.20 \\
(1.72)\end{array}$ \\
\hline Rural Land per Person & & $\begin{array}{l}0.015 \\
(9.35)\end{array}$ & & $\begin{array}{l}0.012 \\
(5.59)\end{array}$ & $\begin{array}{l}0.096 \\
(2.60)\end{array}$ \\
\hline Proportion Urban & & $\begin{array}{c}0.15 \\
(4.65)\end{array}$ & & $\begin{array}{c}0.14 \\
(4.28)\end{array}$ & $\begin{array}{c}0.15 \\
(3.69)\end{array}$ \\
\hline Rural Land per Person Squared & & & & & $\begin{array}{r}-0.023 \\
(2.35)\end{array}$ \\
\hline Pseudo R-Squared & 0.61 & 0.72 & 0.38 & 0.70 & 0.58 \\
\hline Pseudo R-Squared omitting State Effects & 0.20 & 0.39 & 0.14 & 0.24 & 0.40 \\
\hline & r of $\mathrm{Ob}$ & 325 & & & \\
\hline
\end{tabular}

${ }^{2}$ Instruments selected by overidentification test (all exogenous variables, female to male ratio and its square, and squares of castes, muslims and urban). 
Table 2C :Teachers (Abs. Values of t-statistics)

\begin{tabular}{|c|c|c|c|c|c|}
\hline Variable & \multicolumn{2}{|c|}{ SUR Estimates } & \multicolumn{2}{|c|}{ NL3SLS Estimates ${ }^{1}$} & Selected Model ${ }^{2}$ \\
\hline Voter Turnout & $\begin{array}{c}-0.16 \\
(0.68)\end{array}$ & $\begin{array}{c}-0.22 \\
(1.00)\end{array}$ & $\begin{array}{c}0.46 \\
(1.00)\end{array}$ & $\begin{array}{c}-0.044 \\
(0.10)\end{array}$ & $\begin{array}{l}-2.20 \\
(4.01)\end{array}$ \\
\hline Female/Male Voter Turnout & $\begin{array}{c}0.26 \\
(1.86)\end{array}$ & $\begin{array}{c}0.27 \\
(2.52)\end{array}$ & $\begin{array}{c}0.96 \\
(3.12)\end{array}$ & $\begin{array}{c}0.67 \\
(2.90)\end{array}$ & $\begin{array}{c}0.75 \\
(4.91)\end{array}$ \\
\hline Number of Voting Constituencies & $\begin{array}{c}-0.021 \\
(0.61)\end{array}$ & $\begin{array}{l}-0.042 \\
(1.29)\end{array}$ & $\begin{array}{l}-0.087 \\
(1.87)\end{array}$ & $\begin{array}{l}-0.061 \\
(1.73)\end{array}$ & $\begin{array}{c}-0.0065 \\
(0.16)\end{array}$ \\
\hline Proportion Rural Scheduled Caste & $\begin{array}{c}-0.29 \\
(5.13)\end{array}$ & $\begin{array}{c}-0.22 \\
(4.36)\end{array}$ & $\begin{array}{c}-0.32 \\
(6.06)\end{array}$ & $\begin{array}{c}-0.24 \\
(5.03)\end{array}$ & $\begin{array}{c}-0.0033 \\
(0.04)\end{array}$ \\
\hline Proportion Rural Muslim & $\begin{array}{r}-0.057 \\
(2.68)\end{array}$ & $\begin{array}{l}-0.045 \\
(2.46)\end{array}$ & $\begin{array}{l}-0.074 \\
(3.52)\end{array}$ & $\begin{array}{l}-0.053 \\
(3.01)\end{array}$ & $\begin{array}{l}-0.21 \\
(5.39)\end{array}$ \\
\hline Agricultural Output per Person & & $\begin{array}{l}-0.21 \\
(4.48)\end{array}$ & & $\begin{array}{l}-0.19 \\
(3.09)\end{array}$ & $\begin{array}{l}-0.11 \\
(1.66)\end{array}$ \\
\hline Proportion Landless & & $\begin{array}{l}0.020 \\
(0.37)\end{array}$ & & $\begin{array}{l}-0.027 \\
(0.42)\end{array}$ & $\begin{array}{c}0.17 \\
(2.27)\end{array}$ \\
\hline Rural Land per Person & & $\begin{array}{c}0.0018 \\
(1.69)\end{array}$ & & $\begin{array}{c}0.00012 \\
(0.07)\end{array}$ & $\begin{array}{l}0.013 \\
(4.72)\end{array}$ \\
\hline Proportion Urban & & $\begin{array}{l}0.013 \\
(0.52)\end{array}$ & & $\begin{array}{c}0.0038 \\
(0.16)\end{array}$ & $\begin{array}{c}0.00033 \\
(0.01)\end{array}$ \\
\hline Proportion Rural Muslims Squared & & & & & $\begin{array}{l}0.082 \\
(5.34) \\
\end{array}$ \\
\hline Pseudo R-Squared & 0.63 & 0.66 & 0.47 & 0.63 & 0.55 \\
\hline Pseudo R-Squared omitting State Effects & 0.14 & 0.18 & 0.03 & 0.12 & 0.15 \\
\hline
\end{tabular}

${ }^{2}$ Instruments selected by overidentification test (all exogenous variables, female to male ratio and its square, and squares of castes, land and urban). 
BETAGLEA.s99.wpd 